\title{
ASSESSMENT OF OLIVE LEAVES EXTRACT - CYTOTOXICITY IN VITRO AND ANGIOGENESIS IN OVO
}

\author{
MĂDĂLINA BORUGĂ ${ }^{1 \#}$, VIRGIL ENĂTESCU ${ }^{1 \#,}$, IULIA PINNZARU ${ }^{2 *}$, CAMELIA SZUHANEK $^{3}$, \\ DALIANA MINDA ${ }^{2}$, IASMINA MARCOVICI ${ }^{2}$, DANIELA RADU ${ }^{1}$, DANIELA MARȚI ${ }^{4}$, \\ BRIGITHA VLAICU ${ }^{1}$, OANA SUCIU ${ }^{1}$
}

\author{
1 "Victor Babeş" University of Medicine and Pharmacy Timișoara, Faculty of Medcine, 2 Eftimie Murgu Square, 300041, \\ Timişoara, Romania \\ 2 "Victor Babeș" University of Medicine and Pharmacy Timișoara, Faculty of Phamacy, 2 Eftimie Murgu Square, 300041, \\ Timişoara, Romania \\ 3 "Victor Babeş" University of Medicine and Pharmacy Timişoara, Faculty of Dental Medicine, 2 Eftimie Murgu Square, \\ 300041, Timisoara, Romania \\ ${ }^{4}$ Western University Vasile Goldiș, Faculty of Medicine, 94 Revoluției Boulevard, 310025, Arad, Romania
}

*corresponding author: iuliapinzaru@umft.ro

\#Authors with equal contribution.

Manuscript received: May 2020

\begin{abstract}
In this study, it was determined the composition of the olive leaves ethanolic extract by LC-MS, the in vitro cytotoxicity on A375 human melanoma cells was established, by means of the MTT assay (number of viable cells), the Annexin V-FITC assay (number of apoptotic cells) and in vivo irritant and toxic potential by chorioallantoic membrane assay. The extract contains a number of polyphenols, among which luteolin and rutin are the predominant compounds and triterpenic acids with a significant ursolic acid content. At the highest concentration tested, $100 \mu \mathrm{g} / \mathrm{mL}$, it was noted an important cytotoxic effect on human melanoma cells, it influences the development of growing capillaries, it induces narrowed calibre vessels, but no signs of toxicity on HET-CAM were recorded, while $24 \mathrm{~h}$ after treatment, the extract expressed a stronger effect, upon both tumour cell growth and the vascularization of A375 melanoma cells on in vivo test.
\end{abstract}

\section{Rezumat}

S-a determinat compoziția extractului etanolic din frunze de măslin prin LC-MS, citotoxicitatea in vitro pe celule A375, de melanom uman, prin testul MTT (numărul de celule viabile), prin testul Annexin V-FITC (numărul de celule apoptotice) și potențialul iritant și toxic in vivo prin testarea pe membrană corioalantoică. Extractul conține o varietate de polifenoli, dintre care luteolina și rutinul sunt compușii predominanți și acizii triterpenici, cu un conținut semnificativ de acid ursolic. La cea mai mare concentrație testată, $100 \mu \mathrm{g} / \mathrm{mL}$, s-a observat un efect citotoxic important asupra celulelor melanomului uman, influențarea dezvoltării capilarelor în creștere, inducerea vaselor de calibru îngust, dar nu s-au înregistrat semne de toxicitate pe HET-CAM, în timp ce, 24 de ore după tratament, extractul a exprimat un efect mai puternic atât în ceea ce privește creșterea celulelor tumorale, cât și vascularizarea celulelor de melanom A375 la testul in vivo.

Keywords: olive leaves, polyphenols, triterpenes, cytotoxicity, angiogenesis, melanoma

\section{Introduction}

The extract of olive leaves is marketed globally and is considered a natural medicine, which has a number of benefits on maintaining human health. It is rich in different classes of different compounds, which are thought to produce the therapeutic effects of the extract [23]. A major problem regarding the products of natural origin is the one related to the variation of the chemical composition due in particular to the origin, which emphasizes the composition taking into account also the nutrition of the plant, the way of extraction, the form of storage, etc. [10, 11, 20]. Oleanolic, betulinic and ursolic acids are members of the class of triterpenic acids, secondary metabolites of plants, mainly presents in bark and leaves and medicinally the most important compounds from their class [1]. These are currently intensively studied due to the biological effects that they prove and which makes them possible candidates in pharmaceutical and nutraceutical applications. Several studies have highlighted antimicrobial, antitumour, antiallergic, antiinflammatory, hepatoprotective and other activities [18]. Other plant extracts, such as Viscum album, revealed the presence of important terpenoids and the antiproliferative activity was manifested through cytotoxic effects on liver and breast cancer cell lines [22]. The chorioallantoic membrane (CAM) is an extraembryonic membrane, rich vascularized and easily accessible, which is why the CAM assay is commonly used to study angiogenesis, proangiogenic and anti- 
angiogenic effects of natural or synthetic compounds [15]. In addition, immune and nervous systems are not fully developed at the embryonic developmental stages that the experiment is being conducted. CAM can also be used to incorporate tumour tissue to study different aspects of angiogenesis and metastasis which are characteristic of malignant diseases. Due to the large and rich vascularized surface, CAM can be used to determine the potential irritant effect of some substance, as an alternative to the classic Draize rabbit eye assay. Among the advantages of the Hen's Egg Chorioallantoic Membrane Test (HET-CAM), there are mentioned: the possibility of testing a wide range of substances, low time consuming, low costs and good reproducibility [3]. HET-CAM is a quantitative method of a substance irritant effect and involves determining the irritability score that presumes the continuous observation of the CAM after application of the test compound, usually over a period of 300 seconds [6].

The aim of this experiment was to determine the cytotoxicity of olive leaves ethanolic extract on human melanoma cells and to establish the irritant and toxic potential by employing the in vivo chorioallantoic membrane assay using the HET-CAM method.

\section{Materials and Methods}

\section{Reagents}

Solvents, methanol and ethanol, acetic acid, ammonium acetate were acquired from Merck (Darmstadt, Germany) while standard polyphenolic compounds and standard pentacyclic triterpenes were purchased from SigmaAldrich (Germany), 3-(4,5-dimethylthiazol-2-yl)-2,5diphenyltetrazolium bromide (MTT) kit from Roche (Germany), specific cell culture reagents (medium, antibiotic mixture, foetal bovine serum, etc.) from American Type Culture Collection (ATCC). Olive leaves were collected from Ksamil (Southern Albania), certified at the Pharmaceutical Botany Department, Faculty of Pharmacy, Timișoara, Romania, and then dried (at room temperature, away from light, for 10 days) and ground.

\section{Extract preparation}

The ethanolic extract of olive leaves was obtained by maceration, as described by Biris et al. [4]. Briefly, $10 \mathrm{~g}$ of dried material (d.m.) were extracted with $40 \mathrm{~mL}$ ethanol 95\% (room temperature, $250 \mathrm{rpm}, 72 \mathrm{~h}$ ) in an orbital shaker (Incubator Environmental Shaker ES-20/60), then filtered, the solvent was removed with a rotary-evaporator, freeze-dried and stored at $4^{\circ} \mathrm{C}$, protected from light, until further tests.

\section{LC-MS analysis}

The extract was subjected to LC-MS analysis for the quantification of polyphenols and triterpenes. A 6120 LC-MS system from Agilent, Santa Clara, USA was used. OpenLAB CDS ChemStation Workstation software was utilized in order obtains the LC-MS results.
Due to the quantification of two different classes of chemical compounds, two chromatographic methods were applied, namely: (1) for polyphenols - mobile phase $0.1 \% \mathrm{CH}_{3} \mathrm{COOH}$ and $\mathrm{CH}_{3} \mathrm{OH}$, gradient program (0 - 5 min. $5 \% \mathrm{CH}_{3} \mathrm{OH} ; 5$ - 38 minutes gradient $42 \%$ $\mathrm{CH}_{3} \mathrm{OH} ; 38$ - 41 minutes $42 \% \mathrm{CH}_{3} \mathrm{OH} ; 41$ - 42 min. $5 \% \mathrm{CH}_{3} \mathrm{OH}$ ), flow rate $1 \mathrm{~mL} / \mathrm{min}$, injection volume $10 \mu \mathrm{L}$, column temperature $40^{\circ} \mathrm{C}$ (Zorbax Eclipse Plus C18 column; $3.0 \times 100 \mathrm{~mm} \times 3.5 \mu$ ), UV detection at 330 and $370 \mathrm{~nm}$, MS detection in the SIM detection mode, in the negative ion mode, capillary voltage $3500 \mathrm{~V}$, dry gas flow $12 \mathrm{~L} / \mathrm{min}$ at $350^{\circ} \mathrm{C}$ and (2) for triterpenes - mobile phase $1 \mathrm{mM} \mathrm{NH}_{4} \mathrm{CH}_{3} \mathrm{CO}_{2}$ and $\mathrm{CH}_{3} \mathrm{OH}(1: 3 \mathrm{v} / \mathrm{v})$, isocratic elution, flow rate $1 \mathrm{~mL} / \mathrm{min}$, injection volume $20 \mu \mathrm{L}$, column temperature $20^{\circ} \mathrm{C}$ (Ultrasphere ODS C18 column; 4.6 x $250 \mathrm{~mm}$ × $5 \mu$ ), UV detection at 200 and $210 \mathrm{~nm}$, MS detection in the SIM mode, in the negative ion mode, capillary voltage $3500 \mathrm{~V}$, dry gas flow $12 \mathrm{~L} / \mathrm{min}$ at $350^{\circ} \mathrm{C}$. Calibration curves were obtained for the quantification of polyphenols/triterpenes in the samples by the external standard method in the $0.05-2 \mu \mathrm{g} / \mathrm{mL}$ range for a six-point/seven-point plot for each compound. Cytotoxicity in vitro

The human melanoma cell line A375 (ATCC ${ }^{\circledR}$ CRL$1619^{\mathrm{TM}}$ ) was acquired from ATCC and was cultured in Dulbecco's modified Eagle Medium (DMEM) with high glucose, Hepes and L-glutamine, supplemented with antibiotic mixture and foetal calf serum (FCS) as previously described $[9,13]$.

Cells viability was assessed by the microculture tetrazolium assay [2]. Briefly, 10,000 cells/well were seeded in culture plates (96-well) and treated with different concentrations of the tested extract -0.1 , $0.5,10,15$ and $100 \mu \mathrm{g} / \mathrm{mL}$, subsequent $10 \mu \mathrm{L}$ of 5 $\mathrm{mg} / \mathrm{mL}$ MTT solution was added and after $3 \mathrm{~h}$ contact period the precipitated crystals were dissolved in $100 \mu \mathrm{L}$ of lysis solution and the absorbance was read at $570 \mathrm{~nm}$, using a microplate reader (xMark Microplate Spectrophotometer, Bio-Rad, USA). The formula applied to obtain the percentage of cell viability was:

Cell viability $(\%)=100-\left[\left(\mathrm{A}_{0}-\mathrm{A}_{\mathrm{s}}\right) / \mathrm{A}_{0} \mathrm{x} 100\right]$,

where: $A_{0}=$ absorbance of the blank sample and $\mathrm{A}_{\mathrm{s}}=$ absorbance of the tested extract.

Apoptosis assay

Annexin V/PI apoptosis assay was applied in order to estimate the number of apoptotic cells in the presence of olive leaves ethanolic extract. Cells were examined by flow cytometry on FACSCalibur (Becton Dickson, Franklin Lakes, NJ, USA). The protocol was conducted according to the literature: 300,000 A375 human melanoma cells/well were seeded into plates (6-well, flow cytometry was performed with an Annexin VFITC kit acquired from eBioscience, Vienna, Austria) and concentrations from 0.1 to $100 \mu \mathrm{g} / \mathrm{mL}$ of extract were added [21]. 


\section{HET CAM assay}

The evaluation of extracts biocompatibility and toxicity was assessed in vivo by the Hen's Egg Chorioallantoic Membrane Test (HET-CAM), applied in order to evaluate a possible irritant effect on the vascular plexus of the chorioallantoic membrane [12]. Summarily, the eggs (fertilized hen, Gallus gallusdomesticus, eggs) were incubated at $37^{\circ} \mathrm{C}$, controlled humidity; on day 3 of incubation, 3 - $4 \mathrm{~mL}$ of albumen were extracted, on day 4 a window was cut and the eggs were stored in the incubator until day 9; three eggs were utilized for each tested concentration; $500 \mu \mathrm{L}$ of control or test solution was applied and the changes produced at the CAM level were monitored by means of stereomicroscopy. Negative control was phosphate buffer solution (PBS) and positive control was $1 \%$ sodium dodecyl sulphate (SDS) in PBS.

The observation time of the reactions was 300 seconds, by using stereomicroscopy with a Discovery 8 Stereomicroscope Zeiss (Göttingen, Germany) and the time at which the occurrence of a particular reaction took place was noted in seconds, images being recorded with Axio CAM 105 colour, Zeiss and processed using AxioVision SE64. Rel. 4.9.1 Software, Zeiss). The onsets of the following negative events were monitored: haemorrhage $-\mathrm{H}$ (blood vessel bleeding), vascular lysis - L (disintegration of blood vessels), coagulation - C (intra- or extra-vascular protein denaturizing). The most extensively used evaluation is done by calculating an irritation score (IS), using the formula:

$$
\begin{gathered}
\mathrm{IS}=5 \times[(301-\mathrm{Sec} \mathrm{H}) / 300]+7 \times[(301-\mathrm{Sec} \mathrm{L}) / \\
300]+9 \times[(301-\mathrm{Sec} \mathrm{C}) / 300],
\end{gathered}
$$

where: IS - Irritation score, $\mathrm{H}$ - haemorrhage, L vessel lysis, $\mathrm{C}$ - coagulation, Haemorrhage time ( $\mathrm{Sec}$ $\mathrm{H}$ ) - onset of haemorrhage reactions on CAM (in seconds), Lysis time (Sec L) - onset of vessel lysis on CAM (in seconds), Coagulation time ( $\mathrm{Sec} \mathrm{C}$ ) onset of coagulation formation on CAM (in seconds). Irritation severity was evaluated by severity score (SS) as described in the literature [6].

The A375 cells were cultured according to the method described forwards: the cells were harvested from the culture plate, resuspended in culture medium in order to reach the final concentration of $100000 / 3$ $\mu \mathrm{L}$. On the day 10 of incubation, $3 \mu \mathrm{L}$ of the A375 melanoma cell suspension were inoculated while control samples were inoculated with $3 \mu \mathrm{L}$ of cell culture medium and the evaluation was done according to the method described previously in the literature [5].

Statistical analysis

In the current study GraphPad Prism 7 and Flowing Software Version 2.5.1 were utilized in order to obtain the data which were subsequently interpreted using one-way ANOVA. The establishment of statistical differences (control vs. exposed were marked with *; $* * * \mathrm{p}<0.001, * * * * \mathrm{p}<0.0001)$ was realized with Tukey's post-tests.

\section{Results and Discussion}

\section{Polyphenols content}

The OLEM extract was subjected to LC-MS analysis for the purpose of identifying and quantifying major polyphenols and pentacyclic triterpenes. The polyphenols from the extract are presented in Table I (expressed as $\mu \mathrm{g}$ of phytocompound per $\mathrm{g}$ dry weight d.w. lyophilized extract).

Data obtained showed that luteolin and rutin are the most abundant compounds from polyphenols class. The phytochemical characterization of OLEM extract regarding the screening and quantification of pentacyclic triterpenes revealed that ursolic and oleanolic acids are detected, quantified and listed in Table II.

Table I

Polyphenols from OLEM extract identified and quantified by LC-MS

\begin{tabular}{clccc}
\hline No. & Compound name & $\begin{array}{c}\mathrm{Rt} \\
(\mathrm{min})\end{array}$ & $\begin{array}{c}{\left[\mathrm{M}-\mathrm{H}^{+}\right]^{+}} \\
(\mathrm{m} / \mathrm{z})\end{array}$ & $\begin{array}{c}\text { OLEM } \\
(\mu \mathrm{g} / \mathrm{g} \mathrm{d.w} .)\end{array}$ \\
\hline 1. & Caftaric acid & 1.92 & 311 & 10.66 \\
\hline 2. & Gentisic acid & 2.62 & 153 & - \\
\hline 3. & Chlorogenic acid & 6.38 & 353 & - \\
\hline 4. & Caffeic acid & 6.92 & 179 & 437.29 \\
\hline 5. & p-coumaric acid & 10.50 & 163 & 18.23 \\
\hline 6. & Ferulic acid & 13.88 & 193 & 108.86 \\
\hline 7. & Sinapic acid & 15.89 & 223 & - \\
\hline 8. & Hyperoside & 21.48 & 463 & - \\
\hline 9. & Isoquercitrin & 22.61 & 463 & 286.73 \\
\hline 10. & Rutin & 23.12 & 609 & 10386.40 \\
\hline 11. & Myricetin & 24.37 & 317 & 88.76 \\
\hline 12. & Fisetin & 25.71 & 285 & 7.42 \\
\hline 13. & Quercitrin & 26.22 & 447 & 207.62 \\
\hline 14. & Quercetol & 30.43 & 301 & 51.34 \\
\hline 15. & Luteolin & 32.82 & 285 & 12764.30 \\
\hline 16. & Kaempferol & 35.59 & 285 & 13.28 \\
\hline 17. & Apigenin & 36.82 & 269 & 436.27 \\
\hline & & & & \\
\hline
\end{tabular}


Pentacyclic triterpenes from OLEM extract identified and quantified by LC-MS

\begin{tabular}{clccc}
\hline No. & Compound name & $\begin{array}{c}\mathrm{Rt} \\
(\mathrm{min})\end{array}$ & $\begin{array}{c}{\left[\mathrm{M}-\mathrm{H}^{+}\right]^{+}} \\
(\mathrm{m} / \mathrm{z})\end{array}$ & $\begin{array}{c}\text { OLEM } \\
(\mu \mathrm{g} / \mathrm{g} \mathrm{d} . \mathrm{w} .)\end{array}$ \\
\hline 1. & Ursolic acid & 50.88 & 455 & 31994.20 \\
\hline 2. & Oleanolic acid & 57.63 & 455 & 109.67 \\
\hline
\end{tabular}

\section{In vitro activity}

Stimulation of human melanoma cells (A375) was performed with selected concentration of the extract $(0.1,0.5,5,15$ and $100 \mu \mathrm{g} / \mathrm{mL})$ for $24 \mathrm{~h}$. OLEM exerted some minor effects at low concentrations on cells viability: $\sim 99 \%$ viable cells at $0.1 \mu \mathrm{g} / \mathrm{mL}$, $\sim 98 \%$ viable cells at $0.5 \mu \mathrm{g} / \mathrm{mL}$ and $\sim 93 \%$ viable cells at $5 \mu \mathrm{g} / \mathrm{mL}$. As the concentration increases, the number of viable cells shows a decrease, and the results indicated $\sim 86 \%$ viable cells at $15 \mu \mathrm{g} / \mathrm{mL}$ and $\sim 71 \%$ viable cells at $100 \mu \mathrm{g} / \mathrm{mL}$ (Figure 1).

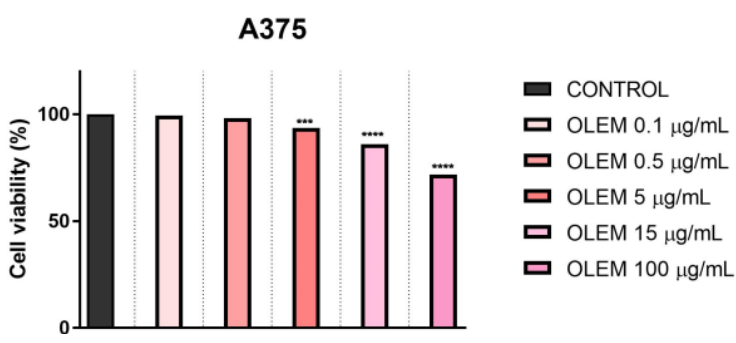

Figure 1.

Percent of viable melanoma cells after stimulation with different concentrations of olive leaves ethanolic extract.

Statistical differences, control vs. exposed cells, were established by one-way ANOVA analysis, followed by Tukey's multiple comparisons post-test; *** $\mathrm{p}<0.001$ and $* * * * \mathrm{p}<0.0001$

The active compounds from olive leaves showed cytotoxic activity on different cell lines, such as leukaemia, colon cancer, breast cancer, especially HER2 positive ones [19]. Methanolic extract of olive leaves tested by $\mathrm{Fu}$ et al. on three breast carcinoma cell lines led to the obtaining values for $\mathrm{IC}_{50}$ between 200 to $300 \mu \mathrm{g} / \mathrm{mL}$ for MCF-7 and SKBR3 cells while for JIMT-1 cells was $>400 \mu \mathrm{g} / \mathrm{mL}$ [7].

In Figure 2 are depicted the percentages of apoptotic cells in the presence of different concentration of
OLEM and as can be observed, at $100 \mu \mathrm{g} / \mathrm{mL}$ the highest number of dead cells was recorded.

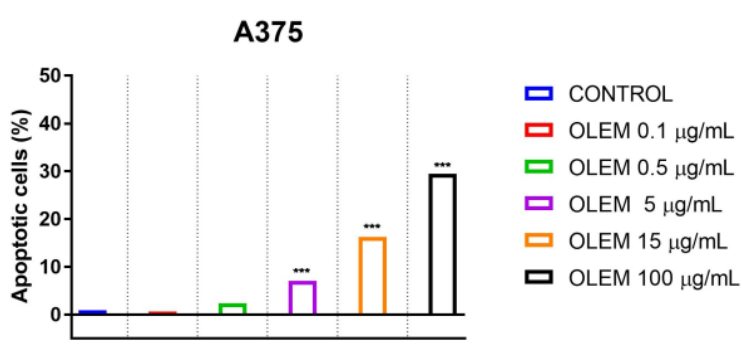

Figure 2.

The percentage of apoptotic melanoma cells after treatment with different concentrations of olive leaves ethanolic extract

Statistical differences, control $v s$. exposed cells, were established by one-way ANOVA analysis, followed by Tukey's multiple comparisons post-test; *** $\mathrm{p}<0.001$

In ovo activity

The reaction induced by the tested extract (Table III) was classified according to Luepke, as follows: 0 - 0.9 non-irritant; 1 - 4.9 weak irritant; 5 - 8.9/9.9 moderate irritant; and 8.9/9.9 - 21 strong irritant as described in the literature $[6,8]$. The effects induced by the tested extract at different concentrations, along with the controls (positive - SDS and negative - PBS) were registered and all three endpoints (haemorrhage, coagulation and lysis) were noticed only for positive control. The OLEM extract at $100 \mu \mathrm{g} / \mathrm{mL}$ showed late and limited signs of both haemorrhage and coagulation, and early though limited signs of vasodilatation which suggests the occurrence of a weak irritant effect at this concentration. The positive control which induced major vascular damage produces death within $60 \mathrm{~min}$., the extract that induced a weak irritant effect produces death within the first 24 hours and the extracts that were non-irritant on the CAM does not affect the viability for more than 24 hours.

Table III

The irritant potential of tested extract

\begin{tabular}{clccc}
\hline No. & Test extract and controls & Irritation score (mean) & Irritation severity (mean) & Classification of the effect \\
\hline 1 & Negative control PBS & 0 & 0 & Non irritant \\
\hline 2 & Positive control SDS & 14.15 & 3 & Strong irritant \\
\hline 3 & OLEM $0.1 \mu \mathrm{g} / \mathrm{mL}$ & 0 & 0 & Non irritant \\
\hline 4 & OLEM $0.5 \mu \mathrm{g} / \mathrm{mL}$ & 0 & 0 & Non irritant \\
\hline 5 & OLEM $5 \mu \mathrm{g} / \mathrm{mL}$ & 0 & 0 & Non irritant \\
\hline 6 & OLEM $15 \mu \mathrm{g} / \mathrm{mL}$ & 0 & 0 & Non irritant \\
\hline 7 & OLEM $100 \mu \mathrm{g} / \mathrm{mL}$ & 0.67 & 1 & Weak irritant \\
\hline
\end{tabular}




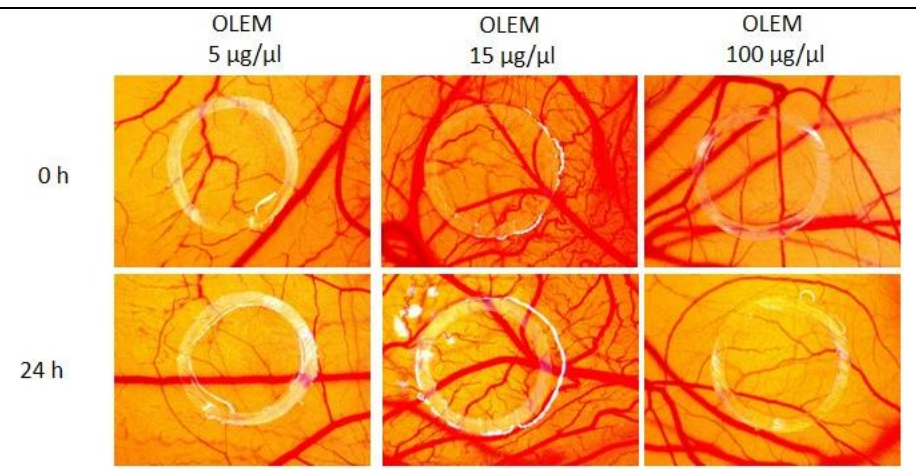

Figure 3.

Irritant potential assessment of test compounds using HET-CAM assay before $(0 \mathrm{~h})$ and after the application $(24 \mathrm{~h})$

OLEM ethanolic extract evaluated during rapid development stage of the vascular plexus, 24 hours after application, influenced the development of growing capillaries, inducing narrowed calibre vessels, but no signs of toxicity (Figure 3).
OLEM $15 \mu \mathrm{g} / \mathrm{mL}$ and OLEM $100 \mu \mathrm{g} / \mathrm{mL} 24 \mathrm{~h}$ after treatment expressed a stronger effect compared to OLEM $5 \mu \mathrm{g} / \mathrm{mL}$, upon both tumour cell growth and the vascularization of A375 melanoma cells, with no spokes wheel angiogenic reaction towards the ring (Figure 4).
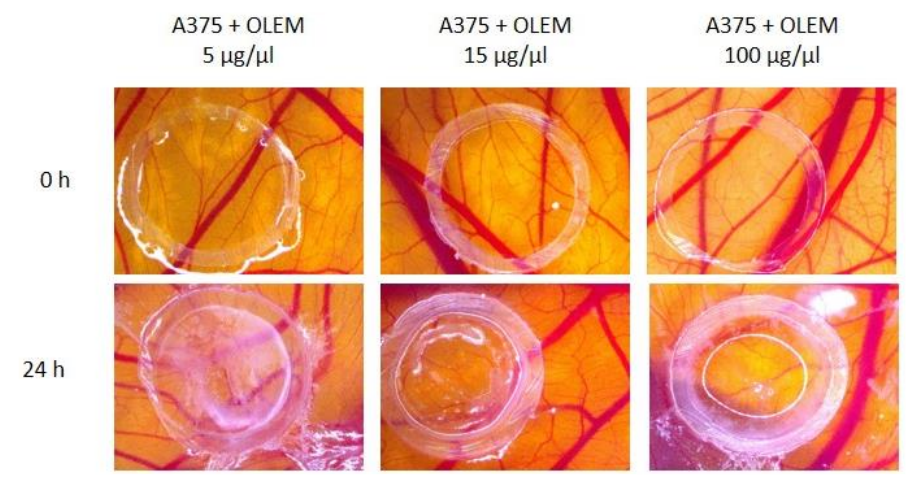

Figure 4.

Effects of OLEM on CAM assay, A375 melanoma cells with three doses of the test extract on day 13

The chorioallantoic membrane of chick embryo is a thin, highly vascularized respiratory extra-embryonary tissue especially applied in cancer and angiogenesis research. Benefitting from an ease of manipulation and assessment, low costs and good reproducibility, it also represents an optimal pre-screening assay to animal models in multiple biological studies, such as: biochemistry, virology, immunology and drug toxicity [14]. The production of a complete inflammatory reaction similar to that induced by irritants to conjunctival tissue makes this model useful in evaluating the potential tolerability and ocular irritation effects of various chemicals [17]. The irritation potential ranges from 0 to 21 and the tested extracts were classified according to this score. This method allows different type of compounds, such as surfactants, cosmetics, other ingredients, different chemical products, dental adhesives etc. to be evaluated as irritant and noxious ingredients [16]. The irritation score and the severity of this effect was evaluated in comparison with strong irritant SDS and the non-irritative PBS, was expressed as moderate and indicated some interference with the vascular function. The HET-
CAM is considered as a good predictive model for the irritation potential and biocompatibility, but still, further comparison is required through other in vitro and in vivo assays.

\section{Conclusions}

The present research was conducted in order to assess cytotoxicity of olive leaves ethanolic extract on human melanoma cells in vitro and to establish the irritant and toxic potential in vivo by HET-CAM method. The extract exerts some cytotoxic effects on melanoma cells at the highest concentration tested, $100 \mu \mathrm{g} / \mathrm{mL}$, and in vivo, at 24 hours after treatment, expressed a stronger effect compared upon both tumour cell growth and the vascularization of A375 melanoma cells.

\section{Acknowledgement}

Part of the in vitro experiments and in vivo experiments were conducted within the Center of Pharmacotoxicological evaluations from the Faculty of Pharmacy, "Victor Babeș" University of Medicine and Pharmacy, Timișoara, Romania. 
Conflict of interest

The authors declare no conflict of interest.

\section{References}

1. Aminfar Z, Rabiei B, Tohidfar M, Mirjalili MH, Identification of key genes involved in the biosynthesis of triterpenic acids in the mint family. Sci Rep., 2019; 9(1): 15826: 1-15.

2. Andor B, Tischer AA, Berceanu-Vaduva D, Lazureanu V, Cheveresan A, Poenaru M, Antimicrobial Activity and Cytotoxic Effect on Gingival Cells of Silver Nanoparticles Obtained by Biosynthesis. Rev Chim. (Bucharest), 2019; 70(3): 781-783.

3. Batista-Duharte A, Jorge Murillo G, Pérez UM, Tur EN, Portuondo DF, Martínez BT, Téllez-Martínez D, Betancourt JE, Pérez O, The Hen's Egg Test on Chorioallantoic Membrane: An Alternative Assay for the Assessment of the Irritating Effect of Vaccine Adjuvants. Int J Toxicol., 2016; 35(6): 627-633.

4. Biris M, Gluhovschi A, Boruga M, Lazureanu V, Moza I, Boruga O, Vlaicu B, Poenaru M, Encapsulation of three different crude extracts rich in triterpenes in a biocompatible polymer and their evaluation in vitro for further applications as anti-inflammatory and/or anti-tumour alternative therapeutic agents. Mater Plast., 2019; 56(1): 282-284.

5. Caunii A, Oprean C, Cristea M, Ivan A, Danciu C, Tatu C, Paunescu V, Marti D, Tzanakakis G, Spandidos DA, Tsatsakis A, Susan R, Soica C, Avram S, Dehelean C, Effects of ursolic and oleanolic on SK-MEL-2 melanoma cells: In vitro and in vivo assays. Int $J$ Oncol., 2017; 51(6): 1651-1660.

6. Coricovac D, Farcas C, Nica C, Pinzaru I, Simu S, Stoian D, Soica C, Proks M, Avram S, Navolan D, Dumitru C, Popovici RA, Dehelean CA, Ethinylestradiol and levonorgestrel as active agents in normal skin, and pathological conditions induced by UVB exposure: In vitro and In ovo assessments. Int J Mol Sci., 2018; 19(11): E3600: 1-26.

7. Fu S, Arráez-Roman D, Segura-Carretero A, Menéndez JA, Menéndez-Gutiérrez MP, Micol V, FernándezGutiérrez A, Qualitative screening of phenolic compounds in olive leaf extracts by hyphenated liquid chromatography and preliminary evaluation of cytotoxic activity against human breast cancer cells. Anal Bioanal Chem., 2010; 397(2): 643-654.

8. Interagency Coordinating Committee on the Validation of Alternative Methods (ICCVAM). ICCVAM Test Method Eval. Rep., 2010; 13: B30-B38.

9. Isaia AI, Ienascu IMC, Andrica FM, Georgescu D, Bratosin D, Pinzaru IA, Preliminary in vitro Evaluation of Seven Different Plant Extracts on A375, B164A5 and HaCat Cell Lines. Rev Chim. (Bucharest), 2016; 67(8): 1633-1636.

10. Lambert de Malezieu M, Courtel P, Sleno L, Abasq ML, Ramassamy C, Synergistic properties of bioavailable phenolic compounds from olive oil: electron transfer and neuroprotective properties. Nutr Neurosci., 2019; 9: $1-14$.

11. López-López A, Cortés-Delgado A, de Castro A, Sánchez AH, Montaño A, Changes in volatile composition during the processing and storage of black ripe olives. Food Res Int., 2019; 125: 108568: 1-9.

12. Meenakshi J, Gandhi VK, Preparation of a Metal and Herbal Nanocomposite (HCNC): Coating onto Wound Dressing Materials and Evaluating its Pharmacological Properties Like Antimicrobial Activity and Biocompatibility. Int J Pharmacol., 2016; 12(6): 633-643.

13. Munteanu MF, Ardelean A, Borcan F, Trifunschi SI, Gligor R, Ardelean SA, Coricovac D, Pinzaru I, Andrica F, Borcan LC, Mistletoe and Garlic Extracts as Polyurethane Carriers - A Possible Remedy for Choroidal Melanoma. Curr Drug Deliv., 2017; 14(8): 1178-1188.

14. Nowak-Sliwinska $P$, Segura T, Iruela-Arispe ML, The chicken chorioallantoic membrane model in biology, medicine and bioengineering. Angiogenesis, 2016; 17(4): 779-804.

15. Ribatti D, Chick embryo chorioallantoic membrane as a useful tool to study angiogenesis. Int Rev Cell Mol Biol., 2008; 270: 181-224.

16. Rosianu RS, Podariu AC, Matei C, Tampa M, Oancea $\mathrm{R}$, Investigation of a hydroxyapatite/tri-calciumphosphate scaffold as carrier for mesenchymal stem cells in alveolar bone regeneration. Rev Chim. (Bucharest), 2014; 65(9): 1049-1051.

17. Schrage A, Gamer AO, Van Ravenzwaay B, Landsiedel R, Experience with the HET-CAM method in the routine testing of a broad variety of chemicals and formulations. Altern Lab Anim., 2010; 38(1): 39-52.

18. Singh B, Sharma RA, Plant terpenes: defense responses, phylogenetic analysis, regulation and clinical applications. 3 Biotech., 2015; 5(2): 129-151.

19. Taamalli A, Arráez-Román D, Barrajón-Catalán E, Ruiz-Torres V, Pérez-Sánchez A, Herrero M, Ibañez E, Micol V, Zarrouk M, Segura-Carretero A, FernándezGutiérrez A, Use of advanced techniques for the extraction of phenolic compounds from Tunisian olive leaves: phenolic composition and cytotoxicity against human breast cancer cells. Food Chem Toxicol., 2012; 50(6): 1817-1825.

20. Torić J, Marković AK, Brala CJ, Barbarić M, Anticancer effects of olive oil polyphenols and their combinations with anticancer drugs. Acta Pharm., 2019; 69(4): 461-482.

21. Tuta-Sas I, Proks M, Paunescu V, Pinzaru I, Sas I, Coricovac D, Moaca A, Dehelean C, Thymus vulgaris extract formulated as cyclodextrin complexes: synthesis, characterization, antioxidant activity and in vitro cytotoxicity assessment. Farmacia, 2019; 67(3): 442-451.

22. Voicu SN, Hermenean A, Olah NK, Badulescu L, Stan MS, Dinischiotu A, Designing new mother tinctures for increased antioxidant efficiency on inflammatory intestinal diseases. Farmacia, 2019; 67(2): 290-295.

23. Wang B, Qu J, Feng S, Chen T, Yuan M, Huang Y, Liao J, Yang R, Ding C, Seasonal Variations in the Chemical Composition of Liangshan Olive Leaves and Their Antioxidant and Anticancer Activities. Foods, 2019; 8(12): 657: 1-17. 